\title{
Specific Basal Forebrain-Cortical Cholinergic Circuits Coordinate Cognitive Operations
}

\author{
[Daszlo Záborszky, ${ }^{1}$ Peter Gombkoto, ${ }^{1}$ Peter Varsanyi, ${ }^{1}$ Matthew R. Gielow, ${ }^{1}$ G Gina Poe, ${ }^{2}$ ㄴorna W. Role, ${ }^{3}$ \\ Mala Ananth, ${ }^{4}$ Prithviraj Rajebhosale, ${ }^{4}$ David A. Talmage, ${ }^{5}$ Michael E. Hasselmo, ${ }^{6}{ }^{\circ}$ Holger Dannenberg, ${ }^{6}$ \\ Victor H. Minces, ${ }^{7}$ and ${ }^{\circledR}$ Andrea A. Chiba ${ }^{7}$ \\ ${ }^{1}$ Center for Molecular and Behavioral Neuroscience, Rutgers University, Newark 07102, ${ }^{2}$ Department of Integrative Biology and Physiology, University of \\ California, Los Angeles 90095, ${ }^{3}$ Department of Neurobiology and Center for Nervous System Disorders, Stony Brook University, Stony Brook, New York \\ 11794, ${ }^{4}$ Program in Neuroscience and Center for Nervous System Disorders, Stony Brook University, Stony Brook, New York 11794, ${ }^{5}$ Department of \\ Pharmacological Sciences and Center for Nervous System Disorders, Stony Brook University, Stony Brook, New York 11794, ${ }^{6}$ Center for Systems \\ Neuroscience and Department of Psychological and Brain Sciences, Boston University, Boston, Massachusetts 02215, and ${ }^{7}$ Department of Cognitive \\ Science, University of California, San Diego 92093
}

Based on recent molecular genetics, as well as functional and quantitative anatomical studies, the basal forebrain (BF) cholinergic projections, once viewed as a diffuse system, are emerging as being remarkably specific in connectivity. Acetylcholine (ACh) can rapidly and selectively modulate activity of specific circuits and ACh release can be coordinated in multiple areas that are related to particular aspects of cognitive processing. This review discusses how a combination of multiple new approaches with more established techniques are being used to finally reveal how cholinergic neurons, together with other BF neurons, provide temporal structure for behavior, contribute to local cortical state regulation, and coordinate activity between different functionally related cortical circuits. ACh selectively modulates dynamics for encoding and attention within individual cortical circuits, allows for important transitions during sleep, and shapes the fidelity of sensory processing by changing the correlation structure of neural firing. The importance of this system for integrated and fluid behavioral function is underscored by its disease-modifying role; the demise of $B F$ cholinergic neurons has long been established in Alzheimer's disease and recent studies have revealed the involvement of the cholinergic system in modulation of anxietyrelated circuits. Therefore, the $\mathrm{BF}$ cholinergic system plays a pivotal role in modulating the dynamics of the brain during sleep and behavior, as foretold by the intricacies of its anatomical map.

Key words: basal forebrain population dynamics; cortico-cortical coherence; cholinergic engram of fear; dynamics of encoding and retrieval; signal and noise correlation

\section{Introduction}

The basal forebrain (BF) is composed of structures including the medial septum, ventral pallidum, vertical and horizontal diagonal band nuclei (VDB, HDB), substantia innominata/extended amygdala (SI/EA), and peripallidal regions; these structures contain a heterogeneous mixture of neuron types that differ in transmitter content, morphology, and projection pattern. A prominent feature of the mammalian $\mathrm{BF}$ is the presence of a collection of aggregated and nonaggregated, large neurons, many of which contain choline acetyl transferase (ChAT), the critical

\footnotetext{
Received Aug. 6, 2018; revised Sept. 11, 2018; accepted Sept. 12, 2018.

This work was funded in part by the National Institutes of Health (Grant R01 MH060013 to M.H.; Grant R01 MH061492 to M.H.; Grant R01 MH060670 to G.P.; National Institute of Neurological Disorders and Stroke Grant (NS023945) to L.Z.); the Office of Naval Research (Grant MURI N00014-16-1-2832 and Grant DURIP N00014-17-12304 to M.H.); the Deutsche Forschungsgemeinschaft (Grant 322014644 to H.D.); the National Science Foundation (Grants SMA 1041755 and IIS 0910485 to A.A.C.); R01 NS022061 to L.W.R; and U01, MH109014 to L.W.R., D.A.T. Helping with the revision by Dr. Candice Chavez is greatly appreciated.

The authors declare no competing financial interests.

Correspondence should be addressed to Laszlo Záborszky, Center for Molecular and Behavioral Neuroscience, Rutgers University, 197 University Avenue, Newark, NJ 07102. E-mail: laszloz@newark.rutgers.edu.

DOI:10.1523/JNEUROSCI.1676-18.2018

Copyright $\odot 2018$ the authors $\quad 0270-6474 / 18 / 389446-13 \$ 15.00 / 0$
}

enzyme in the synthesis of acetylcholine (ACh); these neurons project to the cerebral cortex, the hippocampal complex, and the amygdala. BF areas rich in cholinergic neurons also contain GABAergic, glutamatergic, and peptidergic interneurons and projection neurons in rodents and primates (Gritti et al., 2003; Záborszky et al., 2015b,c). The collection of large, darkly stained (in Nissl sections) neurons, many of which are cholinergic in primates including humans, are referred to as the nucleus basalis of Meynert.

The highly complex BF system has been implicated in cortical activation, affect, attention, sensory coding, motivation, and memory, and in disorders such as Alzheimer's disease (AD), Parkinson's disease, schizophrenia, autism, attention deficit disorder, and drug abuse (Picciotto et al., 2012; Ballinger et al., 2016; Zhang et al., 2016). Although the original description of the cholinergic system in the early 1980s acknowledged that the BF corticopetal system shows some topographic organization (Price and Stern, 1983; Saper, 1984), anatomical data contributed to the BF cholinergic projections being lumped together as part of the "diffuse cortical projection systems" (Saper, 1987). Recent anatomical studies revealed that the cholinergic projection to the 
neocortex is not diffuse, but instead is organized into cortical target-specific groups of cholinergic neurons that receive a specific combination of inputs (Záborszky et al., 2015a; Gielow and Záborszky, 2017). Advances in refined pharmacological techniques have defined a phasic ACh release in a spatially selective fashion in attention and sensory processing and tonic ACh release over broad cortical areas in a brain-state-dependent manner (Parikh et al., 2007; for review, see Ballinger et al., 2016). The observation of spatially specific rapid ACh release (cholinergic "transients") in addition to slower and spatially broader ACh release may reflect the existence of two functionally distinct types of cholinergic neurons (Unal et al., 2012) and could support two different aspects of information processing (Sarter and Kim, 2015).

The timing of ACh release is important for actions throughout the brain, including cortex, hippocampus, and amygdala. Selective cholinergic activation in the prefrontal cortex (PFC) on the scale of subseconds to seconds is associated with cue detection and cue-triggered changes in goal-oriented behavior (goaldriven attention) (Parikh et al., 2007; Gritton et al., 2016; Howe et al., 2017), whereas changes on the scale of minutes may occur over the entire cortex to support more general arousal (Parikh et al., 2007). In the sensory cortex, ACh increases the signal-tonoise ratio of evoked responses and contributes to a change in the correlation structure of intracortical noise (Pinto et al., 2013; Minces et al., 2017), thereby enhancing neuronal response reliability (stimulus-driven attention). The acute enhancement of signal-to-noise ratio could arise from cholinergic depolarization of pyramidal cells and interneurons coupled with presynaptic inhibition of glutamatergic and GABAergic transmission (Patil and Hasselmo, 1999). Over a longer timescale, cholinergic signaling in the hippocampus enhances synaptic plasticity, including LTP (Blitzer et al., 1990; Burgard and Sarvey, 1990) short-term depression, and long-term depotentiation (Huerta and Lisman, 1996), all of which are considered to be cellular substrates of memory and are affected by the precise timing of ACh release in the target area (Blitzer et al., 1990; Burgard and Sarvey, 1990; Gu and Yakel, 2011). Finally, cholinergic signaling in the basolateral amygdala has a state-dependent and largely inhibitory effect on pyramidal cell firing (Unal et al., 2015). This may be important in state-dependent optimization of emotionally salient memories (Jiang et al., 2016). One recent study describes a biologically detailed tissue model of neocortical microcircuitry predicting how ACh affects different types of neurons, synapses, and global network states (Ramaswamy and Markram, 2018) and earlier models addressed the modulation of hippocampal function (Hasselmo et al., 1995; Hasselmo, 2006).

\section{Anatomical organization of the BF cholinergic system}

Using retrograde tracers deposited into disparate cortical areas to map labeled cells in the BF, it was demonstrated that the BF has a complex topographic organization consisting of segregated and overlapping pools of projection neurons. Furthermore, the extent of overlap of BF-projecting populations seems to depend on the degree of connectivity between their cortical targets (Záborszky et al., 2015a).

Preliminary studies (P Varsanyi and L Záborszky, unpublished data) are revealing that BF neurons that project to different cortical targets are organized in BF clusters according to both topographical and functional principles (Fig. 1). For example, cell populations projecting to cortical areas representing different body parts, such as S1 whisker and S1 hindlimb, have very low BF spatial overlap. In contrast, in some $\mathrm{BF}$ areas neurons projecting to $S 1$ are clustered with neurons that project to the corresponding $\mathrm{M} 1$ regions, whereas other areas of the BF contain only $\mathrm{M} 1$ projecting neurons. Similarly, V1 or V2 projecting cells are mostly segregated (see also Huppé-Gourgues et al., 2018), but in specific locations are intermixed with cells projecting to various association areas, including retrosplenial, medial prefrontal, and orbitofrontal cortex. Also, auditory projecting cells may be intermixed with specific somatosensory, perirhinal, prorhinal, and insular cortex projecting cells.

It is envisaged that, in specific clusters, neighboring cholinergic cells may innervate single cortical targets or collateralize to double or triple targets ( $\mathrm{Li}$ et al., 2018). We propose that the clusters in the BF may serve as "modules" that redistribute information from specific locations in the BF to subsets of associated cortical areas, allowing spatially selective modulation of individual or joint cortical areas.

\section{BF cholinergic neurons are modulated by diverse inputs}

Using electron microscopy, BF cholinergic neurons have been shown to receive synaptic inputs from the ventral and dorsal striatum, hypothalamus, amygdala, and brainstem tegmentum. Additionally, adrenaline, noradrenaline, dopamine, GABA, glycine, Vglut1, Vglut2, orexin, somatostatin (SOM), neuropeptide $\mathrm{Y}(\mathrm{NPY})$, substance $\mathrm{P}$, and enkephalin synapses were identified on BF cholinergic neurons (Záborszky and Gombkoto, 2018). Cortical inputs to cholinergic cells were also recently suggested based on monosynaptic virus tracing studies (Do et al., 2016; Hu et al., 2016). For example, it seems that target-identified cholinergic cells receive a specific combination of cortical inputs: motor cortex projecting cholinergic neurons receive a substantial S1-S2 input, whereas cholinergic cells innervating the medial PFC (mPFC) do not receive such input. Conversely, the allocortex contributes $\sim 11 \%$ of the total input to the cholinergic neurons projecting to $\mathrm{mPFC}$ and only $\sim 1 \%$ to the cholinergic neurons projecting to the motor cortex (M1/M2) (Gielow and Záborszky, 2017).

The input dynamics to the $\mathrm{BF}$ cholinergic neurons remain open for investigation because no study to date has investigated the convergence of two or more types of afferents and there is a lack of electrophysiology data about how the various inputs sculpt neuronal firing properties. Cholinergic neurons possess extensive local collaterals (Záborszky et al., 2002); cholinergiccholinergic synapses were described in the septum (Bialowas and Frotscher, 1987) and optogenetic stimulation of cholinergic neurons in slice inhibits spiking of other cholinergic neurons (CT Unal and L Záborszky, unpublished data). The continuously shifting input patterns to cholinergic neurons may reflect environmental salience and behavioral demands that ultimately shift the oscillatory dynamics of the BF for maximal coordination with cortical targets (Quinn et al., 2010; Tingley et al., 2015).

\section{Local neurons in the BF and their interconnections}

As indicated by the complex temporal dynamics of the aggregate of $\mathrm{BF}$ neurons, cholinergic neurons exist in the company of a diversity of cell types of the BF (Záborszky and Gombkoto, 2018). For example, neighboring GABAergic neurons are a diverse cell population in the BF and their axons frequently surround other GABAergic, cholinergic, and glutamatergic neurons in rodents (Záborszky et al., 1986; Henderson et al., 2010). Axons of parvalbumin (PV)-containing GABAergic BF neurons in rats possess few collaterals and some of these synapse with cholinergic dendrites (Záborszky and Duque, 2000), although in optogenetic experiments, stimulation of PV cells did not induce responses in 


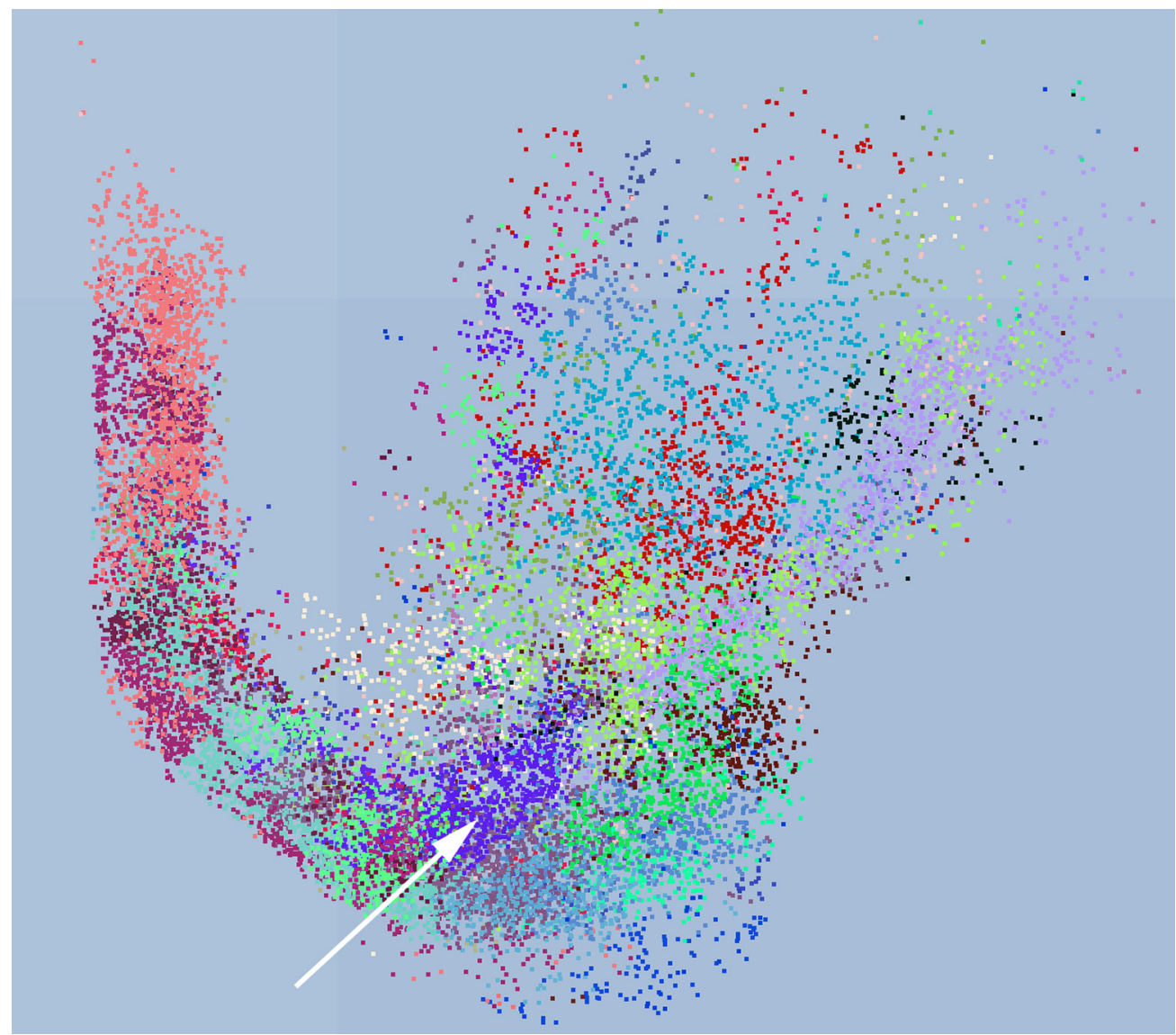

Figure 1. Results of a clustering model using 20 cortical ontology categories and $29 \mathrm{BF}$ clusters. Each cluster is indicated by different color. White arrow points to a large purple cluster containing 1292 cells of which $15 \%$ project to retrosplenial, mPFC and OFC and 12\% to V2. Medial part is the septum, lateral part toward the globus pallidus.

neighboring cholinergic cells (Xu et al., 2015). Cortically projecting BF PV/GABAergic cells are important in regulating cortical gamma band oscillations (Kim et al., 2015), which increases the fidelity of sensory and perceptual coding (Harris and Thiele, 2011; Beaman et al., 2017).

In the rat, many cholinergic neurons projecting to the basolateral nucleus of the amygdala are located in the ventral pallidum and express Vglut3, suggesting that they may release both glutamate and ACh (Nickerson Poulin et al., 2006). Some of the glutamatergic input to cholinergic neurons (Hur et al., 2009) originates in locally arborizing Vglut2 neurons because optogenetic stimulation of Vglut2 neurons excites cholinergic cells (Xu et al., 2015).

A reversed cortical EEG phase relationship exists between BF local NPY and cholinergic cell firing, as demonstrated in anesthetized rats in vivo (Duque et al., 2000). NPY injection into the BF induces changes in cortical EEG in both anesthetized and freely moving rats, suggesting that cholinergic output is regulated by local NPY neurons (Tóth et al., 2005, 2007). NPY local neurons synapse on cholinergic neurons both in the SI/HDB area (Záborszky et al., 2009) and in the caudal globus pallidus/SI area (Nelson and Mooney, 2016). NPY, via NPY Y1 receptors, inhibits the majority of cholinergic neurons. (Záborszky et al., 2009).

SOM has been identified in synapses on cholinergic projection neurons (Záborszky, 1989). A portion of these SOM-containing terminals may originate from local neurons (Záborszky and Duque, 2000). Using in vitro patch-clamp techniques, studies suggest that SOM presynaptically inhibits both GABA and glutamate release onto BF cholinergic neurons (Momiyama and Zá- borszky, 2006). SOM neurons inhibit Vglut2, cholinergic, and PV neurons and receive excitatory input from cholinergic and Vglut2 cells (Xu et al., 2015).

\section{Cholinergic network firing in behaving rodents}

Verified cholinergic neurons in behaving mice were first recorded in 2015 using optogenetic tagging during an auditory sustained attention task (Hangya et al., 2015). Cholinergic neurons responded to primary reinforcers, including innate reward and punishment, with remarkable speed and precision, similarly to responses of putative cholinergic neurons described in the primate (Monosov et al., 2015). Activity in verified cholinergic neurons was also recorded via microendoscopic calcium imaging in mice during spontaneous innate and learned behaviors (Harrison et al., 2016). In contrast to GABAergic or Vglut2 neurons, cholinergic neurons became active at the onset of running and licking and also in response to overt punishment regardless of behavioral context (Harrison et al., 2016). The robust activation of BF cholinergic neurons by movement (Harrison et al., 2016) might mediate the running-induced gain increases evident in sensory cortex (Fu et al., 2014; McGinley et al., 2015).

High-resolution electrophysiological recording of basalocortical networks in awake, behaving rats with optogenetically tagged cholinergic neurons revealed functional connections compatible with meso-scale and large-scale anatomical networks (Záborszky and Gombkoto, 2018). Extracellular spikes were recorded simultaneously in the BF, in the orbitofrontal cortex (OFC), and in the visual association cortex (V2). Several putative functional connections within the BF and between BF and spe- 
cific cortical areas can be recognized (see Fig. 3 in Záborszky and Gombkoto, 2018) using short-latency temporal interactions (Fujisawa et al., 2008). The cholinergic influence in the cortex (Gombkoto et al., 2016) supports the hypothesis that cholinergic modulation of cortical microcircuits is layer specific, corresponding to a layer-specific receptor pattern (Muñoz and Rudy, 2014; Verhoog et al., 2016; Obermayer et al., 2017). Optogenetic stimulation in the BF modulates gamma coherence at spatially specific locations in V2-OFC cortical areas (P Gombkoto and L Záborszky, 2016; P Gombkoto and L Zaborszky, unpublished data), suggesting that the cholinergic system is capable of behavior-dependent modulation of corticocortical functional connectivity, enabling information exchange between interconnected cortical regions. This could involve the cholinergic modulation of feedback synaptic connections weakening local influence and enhancing the influence of longer-range feedforward connections between cortical regions (Hasselmo and Cekic, 1996). These electrophysiological findings, together with the clustered organization of the BF projection system, suggest that the $\mathrm{BF}$ could coordinate activity in remote but associated cortical areas, which is consistent with experiments showing coordinated ACh release in PFC and hippocampus (Teles-Grilo Ruivo et al., 2017). This evidence coincides with recent studies indicating that the firing rate dynamics of individual populations of BF neurons align with the local oscillations in the BF in a nested fashion ("multiplexing"), demonstrating a process whereby coordination of local events in the BF might maximize transfer of information to cortical regions (Tingley et al., 2018).

\section{Relation of cholinergic firing to brain states and networks}

Three basic cortical states are associated with differential BF activity: wake, slow-wave sleep (SWS), and rapid eye movement (REM) sleep (McCormick et al., 2015). Cholinergic neurons show greater activity during waking and REM sleep compared with SWS (Lee et al., 2005; Xu et al., 2015). According to recent studies, finer distinctions can be made in terms of internal cortical dynamics, pupil diameter, and responsiveness to external stimuli (Harris and Thiele, 2011; Vyazovskiy et al., 2011; McGinley et al., 2015). In global SWS, when BF cholinergic firing is low, LFPs and unit firing are characterized by simultaneous slow waves and reduced firing rates in multiple cortical areas and in the hippocampus. Cholinergic inhibitors induce a similar LFP and cell firing state in the hippocampus and cortex of waking animals. Cholinergic agonists will switch the pattern from synchronized slow waves to asynchronous patterns characterizing wakefulness (Jones, 2005). Indeed, unihemispheric sleep in sea mammals, which is characterized by slow waves in only one hemisphere, shows differences in ACh levels between hemispheres, with the synchronous "sleeping" side showing low ACh levels and the asynchronous "awake" side showing high ACh levels (Lapierre et al., 2007). Even within a hemisphere during waking, specific areas may individually display signs of local sleep (Vyazovkiy et al., 2011). Evidence exists that hippocampal theta activity during REM sleep is characterized by especially high ACh levels (Marrosu et al., 1995). The hippocampus and neocortex can display simultaneously starkly different cholinergically controlled EEG/LFP activity patterns (Emrick et al., 2016; Duran et al., 2018), suggesting that separate functional populations of BF neurons project to these areas that are temporally coordinated (see also Teles-Grilo Ruivo et al., 2017). During waking, increased gamma power, enhanced sensory responsiveness, and decreased low-frequency oscillations in the cortex are often paralleled with movement or whisking (Niell and Stryker, 2010;
Eggermann and Feldmeyer, 2009; Lee et al., 2014; Harrison et al., 2016; Nelson and Mooney, 2016).

Analysis of population single-unit spiking dynamics in $\mathrm{V} 2$ and OFC (mentioned above), allowed segregation of states into three groups: local irregular and global UP and DOWN states (Gombkoto et al., 2018). Cholinergic and noncholinergic neurons of the $\mathrm{BF}$ showed either increased modulation or decreased modulation according to cortical state or $\mathrm{BF}$ activity ignored the cortical state change. Figure 2 depicts a cholinergic neuron (BF-ID52) that ignores UP/DOWN states in V2 but is synchronized to UP/ DOWN states to OFC neurons (OFC-ID64). These functional connections may be based on anatomical projections between specific cholinergic neurons and distinct cortical regions.

The mechanism linking cortical arousal, movement-related activity and pupil microdilations remains unexplained but may in part be due to the coordination of the cholinergic system with the noradrenergic system (Reimer et al., 2016; Larsen and Waters, 2018) and the presence of specific brainstem inputs to cholinergic neurons. For example, PFC projecting cholinergic neurons (Gielow and Záborszky, 2017) seem to receive information about pupil diameter and reflex gaze coordination and can broadcast this information to frontal cortex, potentially to modulate attention. Input to cholinergic neurons in the pedunculopontine tegmental, cuneiform, and parabrachial nuclei, largely corresponding to the mesencephalic locomotor region, are good candidates to convey fast movement-related information that accompany cortical membrane desynchronization and arousal (Kaur et al., 2013; Bennett et al., 2014; Lee et al., 2014; Nelson and Mooney, 2016).

In contrast to movement related states, reflective states in humans are said to rely on the default mode network (DMN), supporting functions, including memory, consciousness, and self-reflection (Gusnard et al., 2001; Buckner et al., 2008; Christoff et al., 2009), with similar circuits also described in monkeys and rodents (Lu et al., 2012). Procholinergic drugs (in which systemic administration limits the interpretation) suppress activity in regions that overlap with the DMN (Bentley et al., 2011). Cholinergic stimulation increases task-related activity in dorsolateral frontal and posterior parietal regions, suggesting that the $\mathrm{BF}$ shifts processing states from the DMN to those regions that support processing of external events. The association of the approximate human homolog of the medial septum-diagonal band to activation of the DMN (Yuan et al., 2018) might reflect the anatomical connection between cholinergic neurons in this compartment and the hippocampus, cingulate cortex, and precuneus. Recently, Nair et al. (2018) observed increased gamma activity in the $\mathrm{BF}$ of rats during quiet wakefulness/grooming and suppression of this activity during active exploration of an unfamiliar environment. The investigators suggest that the changing gamma band activity during these behaviors reflects a role for the BF projections to the anterior cingulate cortex (ACC) in switching between internal (DMN) and external events.

\section{Mapping the cholinergic engram of fear and anxiety}

ACh plays a crucial part in the formation of fear memories and might contribute to anxiety-like behaviors. The central nucleus of the amygdala (CeA) registers unexpected events in the environment via its projections to cholinergic neurons in the $\mathrm{BF}$ that are ultimately essential to an animal's ability to increment attention to unexpected events (Chiba et al., 1995; Gallagher and Chiba, 1996; Avery et al., 2012). Through this relay, emotionally salient events in the environment can quickly affect cortical learning (Baxter and Chiba, 1999) via the cholinergic enhance- 
A

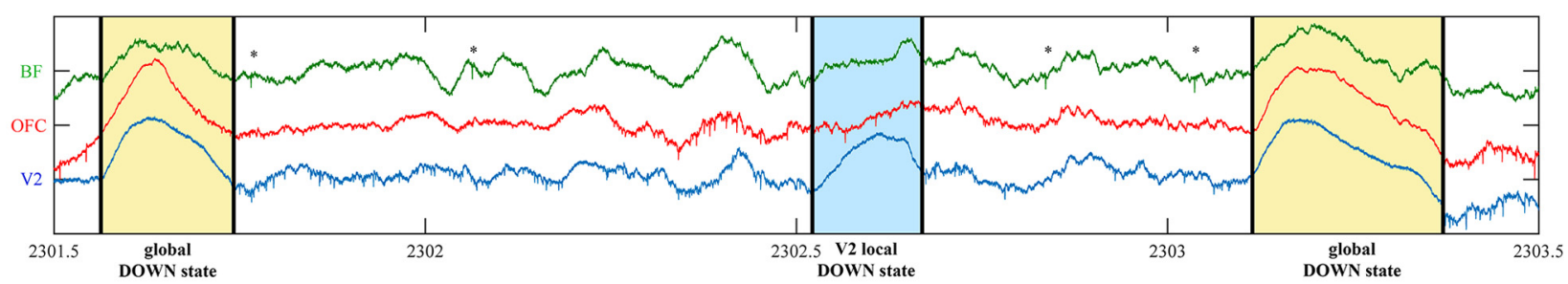

B

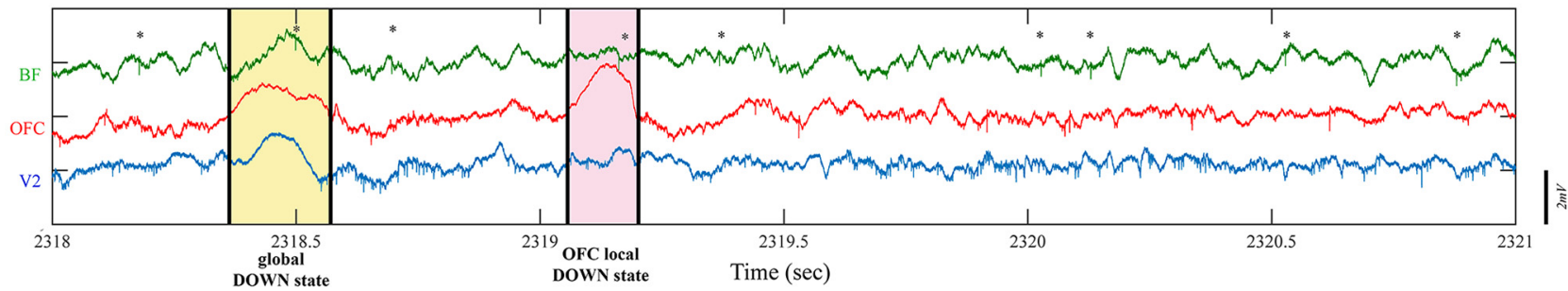

C

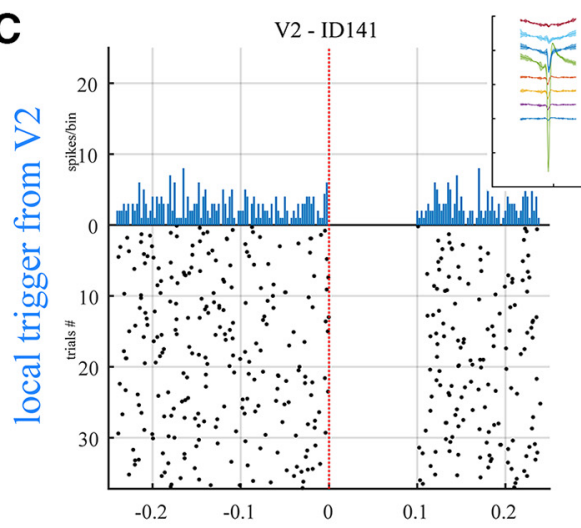

D

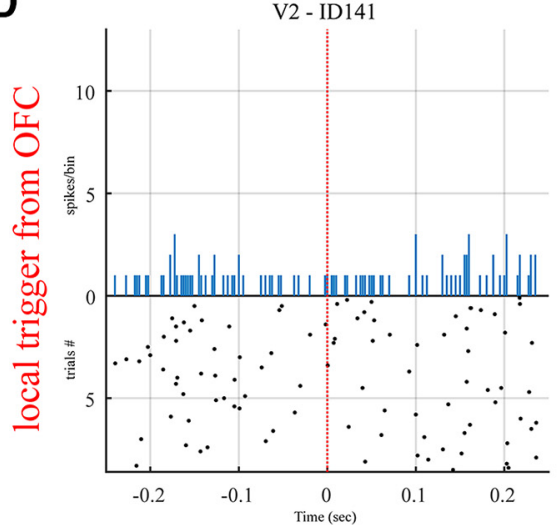

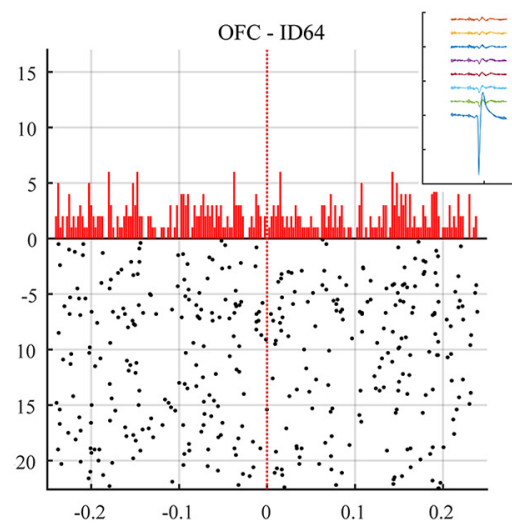

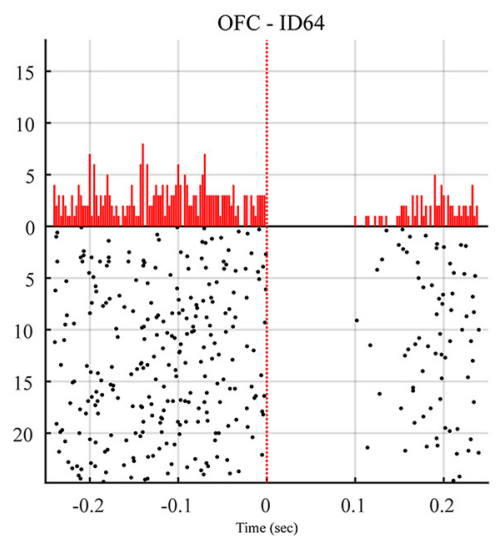

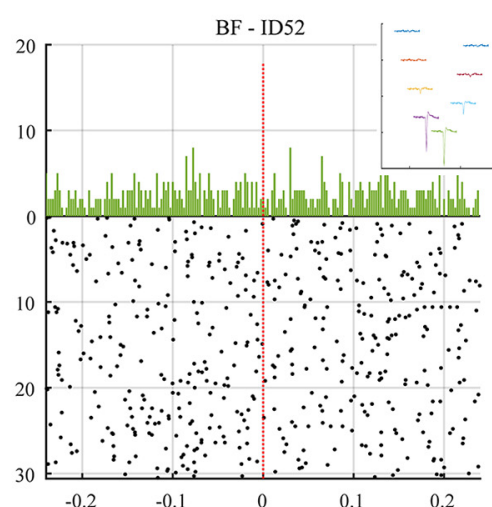

BF - ID52

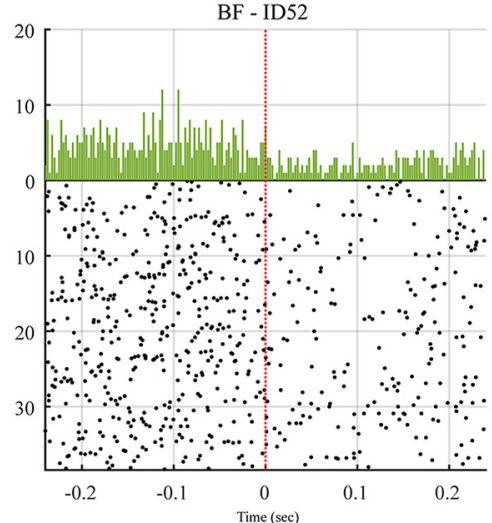

Figure 2. $\quad \boldsymbol{A}, \boldsymbol{B}$, Multisite recording of field and unit activity in the awake rat from BF (green), OFC (red), and V2 (blue) displaying high-amplitude slow fluctuations: UP and DOWN states. Global DOWN states were localized from all structures (yellow areas) and separated from the local DOWN state of V2 ( $\boldsymbol{A}$, blue area) and from 0FC ( $\boldsymbol{B}$, red area). Stars above spikes denote cholinergic firing from BF. C, Peristimulus time histogram (PSTH) of neurons from V2 (first column), OFC (second column), and BF (third column) triggered (red dashed lines) by the onset of the V2 DOWN state. Subplots at upper right corner of each of PSTH shows the spike waveform from silicon electrode arrays. D, PSTH of the same neurons from V1, OFC, and BF triggered by the onset of the DOWN state from OFC locally.

ment of LTP and LTD cited above. Also timed with such events are changes in the ensemble dynamics of the BF (Quinn et al., 2010; Tingley et al., 2015) that may affect the basolateral amygdala (BLA), eliciting changes in intrinsic dynamics and excitability (for review, see Knox, 2016).

Neurons within the BLA are activated during fear behaviors and threat processing (Reijmers et al., 2007; LeDoux, 2012; Amir et al., 2015). BLA neuronal ensembles activated by recall of a fear memory become part of a fear engram (Nonaka et al., 2014); that is, a subset of previously active neurons engaged during learning are reengaged during fear recall. Moreover, direct stimulation of threat-induced, engram-enrolled BLA neurons can elicit fear behavior (Liu et al., 2012; Redondo et al., 2014). The mechanisms that underlie the increased activity of these neuronal ensembles include both changes in intrinsic excitability of neurons and synaptic plasticity (Byrne et al., 1991; Nonaka et al., 2014; Sehgal et al., 2014; Yiu et al., 2014).

BF cholinergic input to the BLA (Carlsen et al., 1985) modulates plasticity of cortico-amygdala synapses and is critical for mediating proper acquisition, recall, and extinction of threat memories (Jiang et al., 2013, 2016). These findings raise the question of whether a coordinated cholinergic input to the BLA con- 


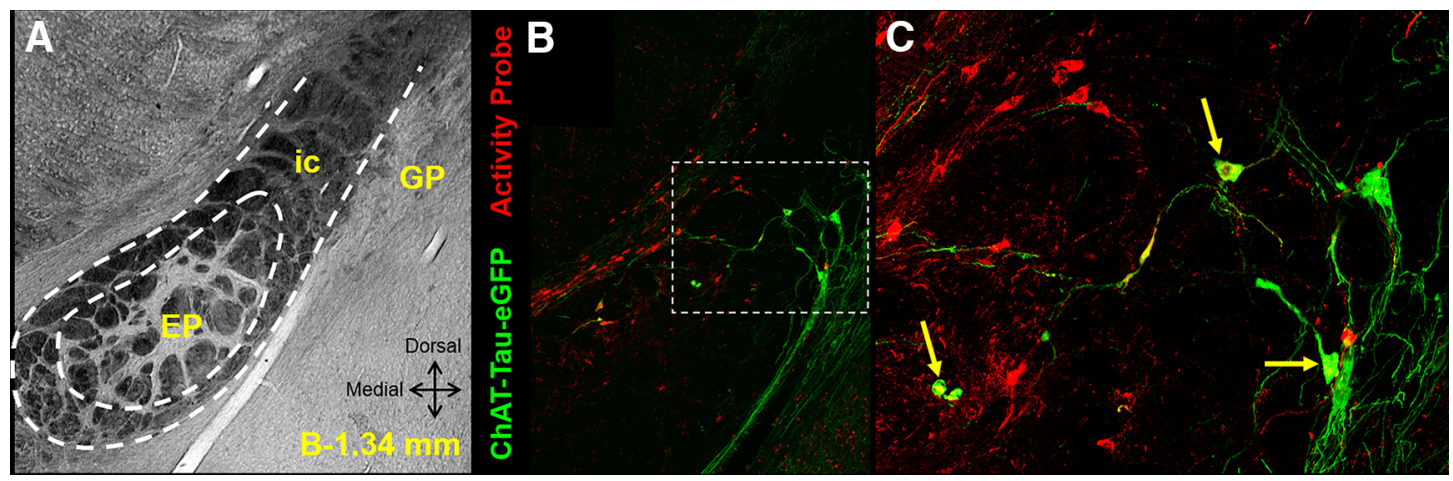

Figure 3. BF cholinergic neurons are activated during fear conditioning. $A$, Transmitted light image showing regions profiled in $B$ and $C$ at bregma at $1.34 \mathrm{~mm}$. EP, Entopeduncular nucleus; ic, internal capsule; GP, globus pallidus. B, AAV-TRE-mCherry-2a-tTA* injected in the nucleus basalis area of a ChAT-tauGFP $\times$ cFos-tTA mouse. Doxycycline transiently removed from the diet opens a labeling window during fear conditioning. White dotted inset delineates region magnified in C. C, Activated cholinergic neurons coexpress mCherry (red) and GFP (green) (yellow arrows). Cholinergic neurons are labeled by GFP. All neurons activated during fear conditioning are labeled by mCherry.

stitutes a cholinergic engram that is essential to the acquisition of conditioned fear (M Ananth, P Rajebhosale, L Jiang, G LopezHernandez, S Wang, N Desai, A Jone, L Role \& D Talmage, unpublished data). This question was addressed using a conditional and inducible gene expression system, allowing examination of the activity of an early immediate gene, cFos, which is associated with long-term adaptive changes within cholinergic neurons, by infecting the BF of cFos-tTA, cFos-shGFP, and ChAT-IRES-Cre triple transgenic mice with a Cre-dependent virus: AAV-TREDIO-mCherry-2a-mut.tTA (Reijmers et al., 2007; Liu et al., 2012). This inducible system allows for permanent marking of active cholinergic neurons during specific time periods (Fig. 3) through viral expression. Infected cholinergic neurons that were active during the first behavior (e.g., fear acquisition) expressed mCherry and those that were reactivated by a previously conditioned stimulus (tone-associated recall) were colabeled with GFP. Electrophysiological examination of these cFos-positive cholinergic neurons revealed increased excitability following threat recall compared with cholinergic neurons that were not activated by threat recall. In other experiments, cholinergicspecific, activity-dependent tags allowed quantification of specific populations of BF cholinergic neurons activated by threat. These data support the existence of a modulatory engram for conditioned fear learning within the cholinergic BF.

Cue-dependent (associative) fear recall is only one aspect of threat-related behaviors. The other aspect involving sustained fear responses is thought to be nonassociative akin to anxiety in humans. It is clearly of great interest to discern circuit mechanisms that might differentiate these associative and nonassociative modules of threat response profiles (Liu et al., 2012; Felix-Ortiz et al., 2013; Kim et al., 2013; Adhikari et al., 2015; Jimenez et al., 2018). Brain regions involved in mediating anxiety-like behaviors in rodents and humans, such as the BLA, $\mathrm{CeA}$, bed nucleus of the stria terminalis, and the ventral hippocampus, are intimately connected to the BF cholinergic system. Predator odors activate these regions within the rodent brain and lead to an anxiety-like behavioral response (Staples, 2010). Lesion and pharmacological studies have shown the influence of cholinergic signaling in the BLA on predator odorinduced freezing behavior (Power and McGaugh, 2002). Mapping the cholinergic activity during exposure to predator odor, identified specific and distinct subsets of activated BF cholinergic neurons, supporting their involvement in modulation of anxiety-related circuits (P Rajebhosale, D Talmage \& W Role, unpublished data). Additionally, the number of cholinergic neu- rons activated during conditioned fear correlated with an animal's behavioral performance (M Ananth, P Rajebhosale, L Jiang, G Lopez-Hernandez, S Wang, N Desai, A Jone, L Role \& D Talmage, unpublished data).

In sum, a combination of viral labeling strategies, rapid acquisition microscopy with high-resolution data extraction (Boor Boor et al., 2018), and electrophysiology provides evidence that specific populations of cholinergic neurons are active during threat-related behaviors and recall (M Ananth, P Rajebhosale, Jiang L, G Lopez-Hernandez, S Wang, N Desai, A Jone, L Role \& D Talmage, unpublished data); that recall-activated cholinergic neurons are more electrically excitable than cholinergic neurons not engaged in recall; that inhibition of cholinergic signaling in the BLA -via either optogenetic or chemogenetic approaches during fear acquisition disrupts recall-induced activation of the BLA (Jiang et al., 2016; M Ananth, P Rajebhosale, L Jiang, G LopezHernandez, S Wang, N Desai, A Jone, L Role \& D Talmage, unpublished data); and that distinct populations of cholinergic neurons may be critically involved in anxiety-related circuits ( $P$ Rajebhosale, D Talmage \& L Role, unpublished data).

\section{Cholinergic neuromodulation affects cellular, synaptic, network, and cognitive functions in the cortex}

$\mathrm{ACh}$ released from $\mathrm{BF}$ axons to the cortex during waking causes cellular effects that appear to enhance memory encoding and attention (Hasselmo, 2006) by enhancing the influence of sensory afferent inputs on cortical activity while reducing the influence of internal corticocortical connections, thereby reducing the internal cortical dynamics associated with memory retrieval (Hasselmo and Bower, 1992; Hasselmo et al., 1995; Hasselmo and Cekic, 1996; Hasselmo, 1999, 2006; Eggermann and Feldmeyer, 2009). Cholinergic enhancement of afferent input is mediated by nicotinic ACh receptors at thalamic axonal inputs to cortex (Vidal and Changeux, 1993; Gil et al., 1997; Metherate and Hsieh, 2003; Disney et al., 2007; Kruglikov and Rudy, 2008; Picciotto et al., 2012). The neuronal spiking response is further enhanced by muscarinic depolarization of cortical neurons (Krnjević et al., 1971; Cole and Nicoll, 1984) and reduction of spike frequency accommodation (Madison et al., 1987; Schwindt et al., 1988) that could enhance memory encoding and attention to sensory afferent input. ACh also causes a strong presynaptic inhibition of excitatory recurrent connections within cortical structures including hippocampus (Valentino and Dingledine, 1981; Herreras et al., 1988; Hasselmo et al., 1995; Vogt and Regehr, 2001), piriform cortex (Hasselmo and Bower, 1992), and neocortex 


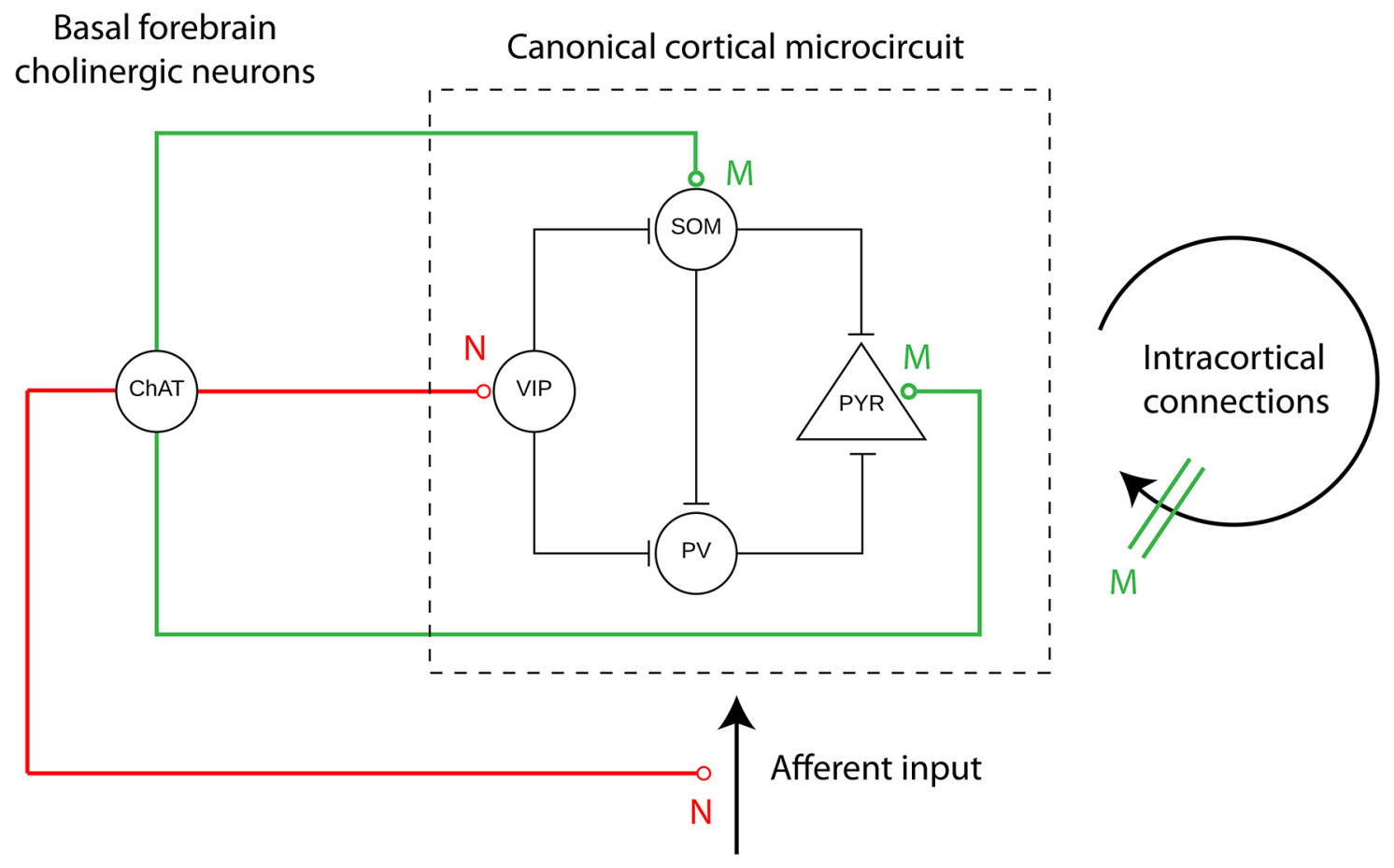

Figure 4. Schematic drawing of cholinergic modulation of a cortical microcircuit. ChAT-positive cholinergic neurons in the BF modulate excitatory glutamatergic PYR cells and three types of inhibitory GABAergic interneurons, VIP-positive, SOM-positive, and PV-positive interneurons. Whereas PV and SOM neurons directly inhibit pyramidal neurons, VIP neurons inhibit SOM and PV neurons, resulting in disinhibition of pyramidal cell activity. Cholinergic modulation acts via nicotinic receptor (N, red) to enhance thalamic input and depolarize VIP neurons and via muscarinic (M, green) ACh receptors to depolarize pyramidal cells and PV and SOM interneurons and cause presynaptic inhibition at excitatory and inhibitory feedback synapses.

(Bröcher et al., 1992; Hasselmo and Cekic, 1996; Hsieh et al., 2000; Eggermann and Feldmeyer, 2009), which could reduce interference from previously encoded memories. Other modulators such as norepinephrine have also been shown to depolarize neurons and regulate synaptic transmission and plasticity, which could underlie the evidence for noradrenergic enhancement of attention and memory function (Hasselmo et al., 1997). Other neurotransmitter systems are active under different sets of conditions and states and do not cause the same neurophysiological activity pattern, so the BF cholinergic system, with its complex anatomy, is a unique system without which attention, memory, sleep patterns, and a host of other functions would be compromised.

Network effects can also be explained by cholinergic modulation of a canonical microcircuit consisting of PV, SOM, and VIP interneurons for cortical inhibition and disinhibition of principal cell activity (Fu et al., 2014; Bell et al., 2015a; Schmitz and Duncan, 2018; Fig. 4). Nicotinic input depolarizes interneurons expressing VIP, which could disinhibit cortical circuits by inhibiting interneurons that express PV and SOM (Fu et al., 2014; Bell et al., 2015b). In contrast, SOM-positive interneurons are depolarized by muscarinic ACh receptors and SOM- and PVpositive interneurons directly inhibit excitatory cells (Kuchibhotla et al., 2017; Young et al., 2017; Desikan et al., 2018). As noted above, cholinergic modulation also affects synaptic plasticity by: enhancing induction of long-term potentiation (Blitzer et al., 1990; Bröcher et al., 1992; Patil et al., 1998), inducing LTD (Williams and Johnston, 1990; Kirkwood et al., 1999; Jo et al., 2010), and biasing spike-timing-dependent plasticity toward LTD (Seol et al., 2007; Brzosko et al., 2017).

Modeling demonstrates how ACh sets appropriate dynamics for encoding new memories without interference from retrieval of previous memories (Hasselmo, 1995, 2006), enhances the signal-to-noise ratio in cortical circuits (Patil and Hasselmo, 1999), and enhances the representation of information by desynchronization and decorrelation of neuronal activity (Pinto et al., 2013; Chen et al., 2015; Minces et al., 2017). For example, modeling shows how cholinergic depolarization of interneurons could enhance GABAergic inhibition of spontaneous background activity, whereas the depolarization of pyramidal cells, suppression of spike frequency accommodation, and presynaptic inhibition of feedback GABAergic transmission can enhance the response to afferent sensory signals (Patil and Hasselmo, 1999). Selective optogenetic stimulation of BF cholinergic neurons increases the signal-to-noise ratio in cortex (Minces et al., 2017). Further computational analyses revealed that neurons achieve this by slightly increasing the signal and generally decreasing the dependency commonly observed between signal and noise correlations. Evidently, this change in the correlation structure of visual cortical neurons increases the encoding capacity of the network (Minces et al., 2017).

Cholinergic muscarinic presynaptic inhibition of excitatory recurrent synapses in the neocortex (Hasselmo and Cekic, 1996; Gil et al., 1997) could account for reduced correlation of neuronal responses during cholinergic input (Goard and Dan, 2009; Pinto et al., 2013) and reduced extent of spatial integration in visual cortex (Roberts et al., 2005; Silver et al., 2008). The muscarinic enhancement of spiking response by depolarization and reduction of spike frequency accommodation could underlie the enhanced response to attended stimuli (Herrero et al., 2008) and enhanced perceptual performance (Pinto et al., 2013).

During active waking and REM sleep, the hippocampus exhibits prominent theta-rhythm oscillations $(4-10 \mathrm{~Hz})$ associated with higher measured levels of ACh (Marrosu et al., 1995; Monmaur et al., 1997; Zhang et al., 2010; Gu et al., 2017). The cholinergic enhancement of theta rhythm (Dannenberg et al., 2015) 
may contribute to encoding, given data showing correlation of encoding with larger theta amplitude. Phase-amplitude coupling of oscillations with theta rhythm may also be important for encoding of new memories (Hasselmo et al., 2002, Colgin et al., 2009) and muscarinic antagonists impair this theta-gamma coupling (Newman et al., 2014). BF cholinergic neurons excite BF GABAergic projection neurons (Yang et al., 2014; Dannenberg et al., 2015) that promote wakefulness (Zant et al., 2016) and theta oscillations. BF oscillatory activity in the theta band can also serve to organize spiking activity and other oscillatory frequencies during behavior, conveying precisely organized information to the cortex (Tingley et al., 2018).

During slow-wave sleep, lower levels of ACh (Marrosu et al., 1995) result in a change in network dynamics relative to waking. The dominant influence of afferent input during high levels of ACh is replaced by lower presynaptic inhibition of excitatory feedback and stronger excitatory feedback potentials (Winson and Abzug, 1977), perhaps underlying the increase of sharp-wave ripples in hippocampus (Buzsáki et al., 1983; Vandecasteele et al., 2014). This enhancement of feedback excitation during low levels of ACh in SWS have been proposed to allow dynamics for consolidation (Buzsáki, 1989; Wilson and McNaughton, 1994; Hasselmo, 1999) and increased ACh during sleep has been shown to impair consolidation (Gais and Born, 2004).

Blockade of ACh receptors has been shown to break down of the spatial specificity of place cells (Brazhnik et al., 2003) and grid cells (Newman et al., 2014), possibly linked to increased excitatory feedback or loss of intrinsic modulation (Heys et al., 2010). This could contribute to the loss of grid cell spatial coding during inactivation of medial septum (Brandon et al., 2011; Koenig et al., 2011). Furthermore, ACh contributes to path integration by facilitating a consistent representation of directionality in head direction cells (Yoder et al., 2017). In summary, the cellular effects of ACh via presynaptic inhibition of excitatory feedback and enhancement of the spiking response to afferent input could contribute to the enhancement of both memory encoding and attention (Hasselmo, 2006).

Consistent with the network effects of cholinergic modulation described here, systemic injection of muscarinic cholinergic antagonists in humans impair sustained attention performance (Wesnes and Warburton, 1984) and impair the encoding of words into memory while sparing retrieval (Ghoneim and Mewaldt, 1977; Peterson, 1977). Learning of new motor actions and motor maps is substantially impaired without BF cholinergic input to cortex (Conner et al., 2003, 2005). Selective manipulation of cholinergic neurons in animal studies causes impairments of sustained attention (McGaughy and Sarter, 1998; Sarter et al., 2005) and ACh release increases with attentional demand (Himmelheber et al., 2000). Selective lesions of cholinergic neurons cause stronger attentional impairments (Chiba et al., 1995, 1999; Fox et al., 2003) than memory impairments (Baxter et al., 1996), but hippocampal memory may involve parallel systems because combined lesions of cholinergic and GABAergic inputs cause stronger effects on memory (Pang et al., 2001) and lesions of cholinergic neurons impair association of objects with spatial location (Cai et al., 2012; Easton and Eacott, 2013).

\section{Cholinergic system in aging and dementia}

Large-scale recordings of the BF indicate that specific cell assemblies of the BF track the ongoing behavioral activities of an animal (Tingley et al., 2014, 2015), organizing cell firing activity according to LFPs that correspond differentially to different stimuli and feedback from the environment (Quinn et al., 2010; Tingley et al.,
2015, 2018). This underscores the importance of BF ensemble activity in maintaining fluid activity in a changing environment and adapting behavior accordingly.

In $\mathrm{AD}$, cholinergic neuron number is reduced and, not surprisingly, patients with mild cognitive impairment (MCI) to early $\mathrm{AD}$ can be distinguished from typical older adults based on their visual scanning and selective attention (Sahakian et al., 1989). Interestingly, both reduced activation of DMN (Sorg et al., 2007; Buckner et al., 2008; Palop and Mucke, 2010) and loss of neurons in basal nucleus of Meynert (Iraizoz et al., 1991; Lehéricy et al., 1993) were reported in AD and the rostral (septal) volume of the cholinergic space shows a reduction in MCI patients that is positively correlated with hippocampal atrophy (Cantero et al., 2017). This also aligns with early changes in the inhibitory networks of the hippocampus that emerge during MCI (Bakker et al., 2012). Interestingly, the cholinergic space shows reduction even during normal aging in humans (Záborszky et al., 2008, 2015c).

Therefore, just as efficient operation of the BF supports functionality, as the network degrades, problems in those areas emerge in the form of an impaired ability to keep track of ongoing behavioral activities, the inability to increment behavior to respond to unexpected events, an inability to effectively decrement attention to irrelevant events, a failure of efficient information transfer to cortex in support of effective sensory coding and new learning, problems with sleep and memory consolidation, and a lack of fluid switching between encoding and retrieval, leading to disorientation, confusion, and lapses of memory and awareness (for review, see Albers et al., 2015; Bondi et al., 2017).

\section{Future directions}

Future studies should investigate whether the putative monosynaptic or oligosynaptic BF ensembles change dynamically during specific behavioral epochs and how firing patterns of selected neurons in the BF affect local cortical circuit dynamics in particular layers. The ability to systematically manipulate the constituent inputs to the BF might also lead to a fuller understanding of the circuit dynamics that allow for the ensemble behavior of the BF. For example, these manipulations could elucidate the potential role of cholinergic neurons in regulating the coding of specific dimensions relevant to behavior and the specificity and timing of the regulation of attention, encoding, and retrieval and consolidation. Future studies can clarify the individual and interactive role of the collective function of the cholinergic neurons in providing a final common pathway to cortical activation and function.

\section{References}

Adhikari A, Lerner TN, Finkelstein J, Pak S, Jennings JH, Davidson TJ, Ferenczi E, Gunaydin LA, Mirzabekov JJ, Ye L, Kim SY, Lei A, Deisseroth K (2015) Basomedial amygdala mediates top-down control of anxiety and fear. Nature 527:179-185. CrossRef Medline

Albers MW, Gilmore GC, Kaye J, Murphy C, Wingfield A, Bennett DA, Boxer AL, Buchman AS, Cruickshanks KJ, Devanand DP, Duffy CJ, Gall CM, Gates GA, Granholm AC, Hensch T, Holtzer R, Hyman BT, Lin FR, McKee AC, Morris JC, et al. (2015) At the interface of sensory and motor dysfunctions and Alzheimer's disease. Alzheimers Dement 11:70-98. CrossRef Medline

Amir A, Lee SC, Headley DB, Herzallah MM, Pare D (2015) Amygdala signaling during foraging in a hazardous environment. J Neurosci 35 : 12994-13005. CrossRef Medline

Avery MC, Nitz DA, Chiba AA, Krichmar JL (2012) Simulation of cholinergic and noradrenergic modulation of behavior in uncertain environments. Front Comput Neurosci 6:5. CrossRef Medline

Bakker A, Krauss GL, Albert MS, Speck CL, Jones LR, Stark CE, Yassa MA, 
Bassett SS, Shelton AL, Gallagher M (2012) Reduction of hippocampal hyperactivity improves cognition in amnestic mild cognitive impairment. Neuron 74:467-474. CrossRef Medline

Ballinger EC, Ananth M, Talmage DA, Role LW (2016) Basal forebrain cholinergic circuits and signaling in cognition and cognitive decline. Neuron 91:1199-1218. CrossRef Medline

Baxter MG, Chiba AA (1999) Cognitive functions of the basal forebrain. Curr Opin Neurobiol 9:178-183. CrossRef Medline

Baxter MG, Bucci DJ, Sobel TJ, Williams MJ, Gorman LK, Gallagher M (1996) Intact spatial learning following lesions of basal forebrain cholinergic neurons. Neuroreport 7:1417-1420. CrossRef Medline

Beaman CB, Eagleman SL, Dragoi V (2017) Sensory coding accuracy and perceptual performance are improved during the desynchronized cortical state. Nat Commun 8:1308. CrossRef Medline

Bell LA, Bell KA, McQuiston AR (2015a) Activation of muscarinic receptors by ACh release in hippocampal CA1 depolarizes VIP but has varying effects on parvalbumin-expressing basket cells. J Physiol 593:197-215. CrossRef Medline

Bell LA, Bell KA, McQuiston AR (2015b) Acetylcholine release in mouse hippocampal CA1 preferentially activates inhibitory-selective interneurons via $\alpha 4 \beta 2^{\star}$ nicotinic receptor activation. Front Cell Neurosci 9:115. CrossRef Medline

Bennett C, Arroyo S, Hestrin S (2014) Controlling brain states. Neuron 83: 260-261. CrossRef Medline

Bentley P, Driver J, Dolan RJ (2011) Cholinergic modulation of cognition: insights from human pharmacological functional neuroimaging. Prog Neurobiol 94:360-388. CrossRef Medline

Bialowas J, Frotscher M (1987) Choline acetyltransferase-immunoreactive neurons and terminals in the rat septal complex: a combined light and electron microscopic study. J Comp Neurol 259:298-307. CrossRef Medline

Blitzer RD, Gil O, Landau EM (1990) Cholinergic stimulation enhances long-term potentiation in the CAl region of rat hippocampus. Neurosci Lett 119:207-210. CrossRef Medline

Bondi MW, Edmonds EC, Salmon DP (2017) Alzheimer's disease: past, present, and future. J Int Neuropsychol Soc 23:818-831. CrossRef Medline

Boor Boor S, Jadhav S, Ananth M, Talmage D, Role L, Kaufman A (2018) Visualization of neuronal structures in wide-field microscopy brain images. IEEE Trans Vis Comput Graph. Retrieved Aug 20, 2018. Advance online publication. doi: 10.1109/TVCG.2018.2864852.

Brandon MP, Bogaard AR, Libby CP, Connerney MA, Gupta K, Hasselmo ME (2011) Reduction of theta rhythm dissociates grid cell spatial periodicity from directional tuning. Science 332:595-599. CrossRef Medline

Brazhnik ES, Muller RU, Fox SE (2003) Muscarinic blockade slows and degrades the location-specific firing of hippocampal pyramidal cells. J Neurosci 23:611-621. CrossRef Medline

Bröcher S, Artola A, Singer W (1992) Agonists of cholinergic and noradrenergic receptors facilitate synergistically the induction of long-term potentiation in slices of rat visual cortex. Brain Res 573:27-36. CrossRef Medline

Brzosko Z, Zannone S, Schultz W, Clopath C, Paulsen O (2017) Sequential neuromodulation of Hebbian plasticity offers mechanism for effective reward-based navigation. Elife 6:e27756. CrossRef Medline

Buckner RL, Andrews-Hanna JR, Schacter DL (2008) The brain's default network: anatomy, function, and relevance to disease. Ann N Y Acad Sci 1124:1-38. CrossRef Medline

Burgard EC, Sarvey JM (1990) Muscarinic receptor activation facilitates the induction of long-term potentiation (LTP) in the rat dentate gyrus. Neurosci Lett 116:34-39. CrossRef Medline

Buzsáki G (1989) Two-stage model of memory trace formation: a role for "noisy" brain states. Neuroscience 31:551-570. CrossRef Medline

Buzsáki G, Leung LW, Vanderwolf CH (1983) Cellular bases of hippocampal EEG in the behaving rat. Brain Res 287:139-171. Medline

Byrne JH, Baxter DA, Buonomano DV, Cleary LJ, Eskin A, Goldsmith JR, McClendon E, Nazif FA, Noel F, Scholz KP (1991) Aspects of the neural and molecular bases of short-and long-term forms of non-associative learning in Aplysia. Ann N Y Acad Sci 627:124-149. CrossRef Medline

Cai L, Gibbs RB, Johnson DA (2012) Recognition of novel objects and their location in rats with selective cholinergic lesion of the medial septum. Neurosci Lett 506:261-265. CrossRef Medline

Cantero JL, Záborszky L, Atienza M (2017) Volume loss of the nucleus basa- lis of meynert is associated with atrophy of innervated regions in mild cognitive impairment. Cereb Cortex 27:3881-3889. CrossRef Medline

Carlsen J, Záborszky L, Heimer L (1985) Cholinergic projections from the basal forebrain to the basolateral amygdaloid complex: a combined retrograde fluorescent and immunohistochemical study. J Comp Neurol 234:155-167. CrossRef Medline

Chen N, Sugihara H, Sur M (2015) An acetylcholine-activated microcircuit drives temporal dynamics of cortical activity. Nat Neurosci 18:892-902. CrossRef Medline

Chiba AA, Bucci DJ, Holland PC, Gallagher M (1995) Basal forebrain cholinergic lesions disrupt increments but not decrements in conditioned stimulus processing. J Neurosci 15:7315-7322. CrossRef Medline

Chiba AA, Bushnell PJ, Oshiro WM, Gallagher M (1999) Altered selective attention in rats with cholinergic lesions of the substantia innominata. Neuroreport 10:3119-3123. CrossRef Medline

Christoff K, Gordon AM, Smallwood J, Smith R, Schooler JW (2009) Experience sampling during fMRI reveals default network and executive system contributions to mind wandering. Proc Natl Acad Sci U S A 106: 8719-8724. CrossRef Medline

Cole AE, Nicoll RA (1984) The pharmacology of cholinergic excitatory responses in hippocampal pyramidal cells. Brain Res 305:283-290. CrossRef Medline

Colgin LL, Denninger T, Fyhn M, Hafting T, Bonnevie T, Jensen O, Moser MB, Moser EI (2009) Frequency of gamma oscillations routes flow of information in the hippocampus. Nature 462:353-357. CrossRef Medline

Conner JM, Culberson A, Packowski C, Chiba AA, Tuszynski MH (2003) Lesions of the basal forebrain cholinergic system impair task acquisition and abolish cortical plasticity associated with motor skill learning. Neuron 38:819-829. CrossRef Medline

Conner JM, Chiba AA, Tuszynski MH (2005) The basal forebrain cholinergic system is essential for cortical plasticity and functional recovery following brain injury. Neuron 46:173-179. CrossRef Medline

Dannenberg H, Pabst M, Braganza O, Schoch S, Niediek J, Bayraktar M, Mormann F, Beck H (2015) Synergy of direct and indirect cholinergic septo-hippocampal pathways coordinates firing in hippocampal networks. J Neurosci 35:8394-8410. CrossRef Medline

Desikan S, Koser DE, Neitz A, Monyer H (2018) Target selectivity of septal cholinergic neurons in the medial and lateral entorhinal cortex. Proc Natl Acad Sci U S A 115:E2644-E2652. CrossRef Medline

Disney AA, Aoki C, Hawken MJ (2007) Gain modulation by nicotine in macaque v1. Neuron 56:701-713. CrossRef Medline

Do JP, Xu M, Lee SH, Chang WC, Zhang S, Chung S, Yung TJ, Fan JL, Miyamichi K, Luo L, Dan Y (2016) Cell type-specific long-range connections of basal forebrain circuit. Elife 5:e13214. CrossRef Medline

Duque A, Balatoni B, Detari L, Záborszky L (2000) EEG correlation of the discharge properties of identified neurons in the basal forebrain. J Neurophysiol 84:1627-1635. CrossRef Medline

Duran E, Oyanedel CN, Niethard N, Inostroza M, Born J (2018) Sleep stage dynamics in neocortex and hippocampus. Sleep 41:6. CrossRef Medline

Easton A, Eacott MJ (2013) Cholinergic mechanisms of episodic memory: what specific behavioural tasks can tell us about specific neural mechanisms. Brain Res Bull 92:21-28. CrossRef Medline

Eggermann E, Feldmeyer D (2009) Cholinergic filtering in the recurrent excitatory microcircuit of cortical layer 4. Proc Natl Acad Sci U S A 106: 11753-11758. CrossRef Medline

Emrick JJ, Gross BA, Riley BT, Poe GR (2016) Different simultaneous sleep states in the hippocampus and neocortex. Sleep 39:2201-2209. CrossRef Medline

Felix-Ortiz AC, Beyeler A, Seo C, Leppla CA, Wildes CP, Tye KM (2013) BLA to vHPC inputs modulate anxiety-related behaviors. Neuron 79: 658-664. CrossRef Medline

Fox MT, Barense MD, Baxter MG (2003) Perceptual attentional set-shifting is impaired in rats with neurotoxic lesions of posterior parietal cortex. J Neurosci 23:676-681. CrossRef Medline

Fu Y, Tucciarone JM, Espinosa JS, Sheng N, Darcy DP, Nicoll RA, Huang ZJ, Stryker MP (2014) A cortical circuit for gain control by behavioral state. Cell 156:1139-1152. CrossRef Medline

Fujisawa S, Amarasingham A, Harrison MT, Buzsáki G (2008) Behaviordependent short term assembly dynamics in the medial prefrontal cortex. Nat Neurosci 11:823-833. CrossRef Medline

Gais S, Born J (2004) Low acetylcholine during slow-wave sleep is critical for 
declarative memory consolidation. Proc Natl Acad Sci U S A 101:21402144. CrossRef Medline

Gallagher M, Chiba AA (1996) The amygdala and emotion. Curr Opin Neurobiol 6:221-227. CrossRef Medline

Ghoneim MM, Mewaldt SP (1977) Studies on human memory: the interactions of diazepam, scopolamine, and physostigmine. Psychopharmacology 52:1-6. CrossRef Medline

Gielow MR, Záborszky L (2017) The input-output relationship of the cholinergic basal forebrain. Cell Rep 18:1817-1830. CrossRef Medline

Gil Z, Connors BW, Amitai Y (1997) Differential regulation of neocortical synapses by neuromodulators and activity. Neuron 19:679-686. CrossRef Medline

Goard M, Dan Y (2009) Basal forebrain activation enhances cortical coding of natural scenes. Nat Neurosci 12:1444-1449. CrossRef Medline

Gombkoto P, Varsanyi P, Záborszky L (2018) Contribution of the basal forebrain to fine-tuned cortical states during a visual discrimination task in rats. Soc Neurosci Abstract 44:510.02.

Gombkoto P, Gielow M, Chavez C, Záborszky L (2016) High density recording in rat basalo-cortical networks. Soc Neurosci Abstr 42:83.05.

Gritti I, Manns ID, Mainville L, Jones BE (2003) Parvalbumin, calbindin, or calretinin in cortically projecting and GABAergic, cholinergic, or glutamatergic basal forebrain neurons of the rat. J Comp Neurol 458:11-31. CrossRef Medline

Gritton HJ, Howe WM, Mallory CS, Hetrick VL, Berke JD, Sarter M (2016) Corical cholinergic signaling controls the detection of cues. Proc Natl Acad Sci U S A 113:E1089-E1097. CrossRef Medline

Gu Z, Yakel JL (2011) Timing-dependent septal cholinergic induction of dynamic hippocampal synaptic plasticity. Neuron 71:155-165. CrossRef Medline

Gu Z, Alexander GM, Dudek SM, Yakel JL (2017) Hippocampus and entorhinal cortex recruit cholinergic and NMDA receptors separately to generate hippocampal theta oscillations. Cell Rep 21:3585-3595. CrossRef Medline

Gusnard DA, Akbudak E, Shulman GL, Raichle ME (2001) Medial prefrontal cortex and self-referential mental activity: relation to a default mode of brain function. Proc Natl Acad Sci U S A 98:4259-4264. CrossRef Medline

Hangya B, Ranade SP, Lorenc M, Kepecs A (2015) Central cholinergic neurons are rapidly recruited by reinforcement feedback. Cell 162:11551168. CrossRef Medline

Harris KD, Thiele A (2011) Cortical state and attention. Nat Rev Neurosci 12:509-523. CrossRef Medline

Harrison TC, Pinto L, Brock JR, Dan Y (2016) Calcium imaging of basal forebrain activity during innate and learned behaviors. Front Neural Circuits 10:36. CrossRef Medline

Hasselmo ME (1995) Neuromodulation and cortical function: modeling the physiological basis of behavior. Behav Brain Res 67:1-27. CrossRef Medline

Hasselmo ME (1999) Neuromodulation: acetylcholine and memory consolidation. Trends Cogn Sci 3:351-359. CrossRef Medline

Hasselmo ME (2006) The role of acetylcholine in learning and memory. Curr Opin Neurobiol 16:710-715. CrossRef Medline

Hasselmo ME, Bower JM (1992) Cholinergic suppression specific to intrinsic not afferent fiber synapses in rat piriform (olfactory) cortex. J Neurophysiol 67:1222-1229. CrossRef Medline

Hasselmo ME, Cekic M (1996) Suppression of synaptic transmission may allow combination of associative feedback and self-organizing feedforward connections in the neocortex. Behav Brain Res 79:153-161. CrossRef Medline

Hasselmo ME, Schnell E, Barkai E (1995) Dynamics of learning and recall at excitatory recurrent synapses and cholinergic modulation in rat hippocampal region CA3. J Neurosci 15:5249-5262. CrossRef Medline

Hasselmo ME, Linster C, Patil M, Ma D, Cekic M (1997) Noradrenergic suppression of synaptic transmission may influence cortical "signal-tonoise" ratio. J Neurophysiol 77:3326-3339. CrossRef Medline

Hasselmo ME, Bodelón C, Wyble BP (2002) A proposed function for hippocampal theta rhythm: separate phases of encoding and retrieval enhance reversal of prior learning. Neural Comput 14:793-817. CrossRef Medline

Henderson Z, Lu CB, Janzsó G, Matto N, McKinley CE, Yanagawa Y, Halasy $\mathrm{K}$ (2010) Distribution and role of Kv3.1b in neurons in the medial sep- tum diagonal band complex. Neuroscience 166:952-969. CrossRef Medline

Herreras O, Solís JM, Herranz AS, Martín del Río R, Lerma J (1988) Sensory modulation of hippocampal transmission. II. Evidence for a cholinergic locus of inhibition in the schaffer-CA1 synapse. Brain Res 461:303-313. CrossRef Medline

Herrero JL, Roberts MJ, Delicato LS, Gieselmann MA, Dayan P, Thiele A (2008) Acetylcholine contributes through muscarinic receptors to attentional modulation in V1. Nature 454:1110-1114. CrossRef Medline

Heys JG, Giocomo LM, Hasselmo ME (2010) Cholinergic modulation of the resonance properties of stellate cells in layer II of medial entorhinal cortex. J Neurophysiol 104:258-270. CrossRef Medline

Himmelheber AM, Sarter M, Bruno JP (2000) Increases in cortical acetylcholine release during sustained attention performance in rats. Brain Res Cogn Brain Res 9:313-325. CrossRef Medline

Howe WM, Gritton HJ, Lusk NA, Roberts EA, Hetrick VL, Berke JD, Sarter M (2017) Acetylcholine release in prefrontal cortex promotes gamma oscillations and theta-gamma coupling during cue detection. J Neurosci 37: 3215-3230. CrossRef Medline

Hsieh CY, Cruikshank SJ, Metherate R (2000) Differential modulation of auditory thalamocortical and intracortical synaptic transmission by cholinergic agonist. Brain Res 880:51-64. CrossRef Medline

Hu R, Jin S, He X, Xu F, Hu J (2016) Whole-brain monosynaptic afferent inputs to basal forebrain cholinergic system. Front Neuroanat 10:98. CrossRef Medline

Huerta PT, Lisman JE (1996) Low-frequency stimulation at the troughs of theta-oscillation induces long-term depression of previously potentiated CA1 synapses. J Neurophysiol 75:877-884. CrossRef Medline

Huppé-Gourgues F, Jegouic K, Vaucher E (2018) Topographic organization of cholinergic innervation from the basal forebrain to the visual cortex in the rat. Front Neural Circuits 12:19. CrossRef Medline

Hur EE, Edwards RH, Rommer E, Záborszky L (2009) Vesicular glutamate transporter 1 and vesicular glutamate transporter 2 synapses on cholinergic neurons in the sublenticular gray of the rat basal forebrain: a doublelabel electron microscopic study. Neuroscience 164:1721-1731. CrossRef Medline

Iraizoz I, de Lacalle S, Gonzalo LM (1991) Cell loss and nuclear hypertrophy in topographical subdivisions of the nucleus basalis of Meynert in Alzheimer's disease. Neuroscience 41:33-40. CrossRef Medline

Jiang L, Emmetsberger J, Talmage DA, Role LW (2013) Type III neuregulin 1 is required for multiple forms of excitatory synaptic plasticity of mouse cortico-amygdala circuits. J Neurosci 33:9655-9666. CrossRef Medline

Jiang L, Kundu S, Lederman JD, López-Hernández GY, Ballinger EC, Wang S, Talmage DA, Role LW (2016) Cholinergic signaling controls conditioned fear behaviors and enhances plasticity of cortical-amygdala circuits. Neuron 90:1057-1070. CrossRef Medline

Jimenez JC, Su K, Goldberg AR, Luna VM, Biane JS, Ordek G, Zhou P, Ong SK, Wright MA, Zweifel L, Paninski L, Hen R, Kheirbek MA (2018) Anxiety cells in a hippocampal-hypothalamic circuit. Neuron 97:670683.e6. CrossRef Medline

Jo J, Son GH, Winters BL, Kim MJ, Whitcomb DJ, Dickinson BA, Lee YB, Futai K, Amici M, Sheng M, Collingridge GL, Cho K (2010) Muscarinic receptors induce LTD of NMDAR EPSCs via a mechanism involving hippocalcin, AP2 and PSD-95. Nat Neurosci 13:1216-1224. CrossRef Medline

Jones BE (2005) Basic mechanisms of sleep-wake states. In: Principles and practice of sleep medicine (Kryger MH, Roth T, Dement WC, eds), pp 136-153. New York: Elsevier Saunders.

Kaur S, Pedersen NP, Yokota S, Hur EE, Fuller PM, Lazarus M, Chamberlin NL, Saper CB (2013) Glutamatergic signaling from the parabrachial nucleus plays a critical role in hypercapnic arousal. J Neurosci 33:7627-7640. CrossRef Medline

Kim SY, Adhikari A, Lee SY, Marshel JH, Kim CK, Mallory CS, Lo M, Pak S, Mattis J, Lim BK, Malenka RC, Warden MR, Neve R, Tye KM, Deisseroth K (2013) Diverging neural pathways assemble a behavioural state from separable features in anxiety. Nature 496:219-223. CrossRef Medline

Kim T, Thankachan S, McKenna JT, McNally JM, Yang C, Choi JH, Chen L, Kocsis B, Deisseroth K, Strecker RE, Basheer R, Brown RE, McCarley RW (2015) Cortically projecting basal forebrain parvalbumin neurons regulate cortical gamma band oscillations. Proc Natl Acad Sci U S A 112:35353540. CrossRef Medline

Kirkwood A, Rozas C, Kirkwood J, Perez F, Bear MF (1999) Modulation of 
long-term synaptic depression in visual cortex by acetylcholine and norepinephrine. J Neurosci 19:1599-1609. CrossRef Medline

Knox D (2016) The role of basal forebrain cholinergic neurons in fear and extinction memory. Neurobiol Learn Mem 133:39-52. CrossRef Medline

Koenig J, Linder AN, Leutgeb JK, Leutgeb S (2011) The spatial periodicity of grid cells is not sustained during reduced theta oscillations. Science 332: 592-595. CrossRef Medline

Krnjević K, Pumain R, Renaud L (1971) The mechanism of excitation by acetylcholine in the cerebral cortex. J Physiol 215:247-268. CrossRef Medline

Kruglikov I, Rudy B (2008) Perisomatic GABA release and thalamocortical integration onto neocortical excitatory cells are regulated by neuromodulators. Neuron 58:911-924. CrossRef Medline

Kuchibhotla KV, Gill JV, Lindsay GW, Papadoyannis ES, Field RE, Sten TA, Miller KD, Froemke RC (2017) Parallel processing by cortical inhibition enables context-dependent behavior. Nat Neurosci 20:62-71. CrossRef Medline

Lapierre JL, Kosenko PO, Lyamin OI, Kodama T, Mukhametov LM, Siegel JM (2007) Cortical acetylcholine release lateralized during asymmetrical slow-wave sleep in northern fur seals. J Neurosci 27:11999-12006. CrossRef Medline

Larsen RS, Waters J (2018) Neuromodulatory correlates of pupil dilation. Front Neural Circuits 12:21. CrossRef Medline

LeDoux J (2012) Rethinking the emotional brain. Neuron 73:653-676. CrossRef Medline

Lee AM, Hoy JL, Bonci A, Wilbrecht L, Stryker MP, Niell CM (2014) Identification of a brainstem circuit regulating visual cortical state in parallel with locomotion. Neuron 83:455-466. CrossRef Medline

Lee MG, Hassani OK, Alonso A, Jones BE (2005) Cholinergic basal forebrain neurons burst with theta during waking and paradoxical sleep. J Neurosci 25:4365-4369. CrossRef Medline

Lehéricy S, Hirsch EC, Cervera-Piérot P, Hersh LB, Bakchine S, Piette F, Duyckaerts C, Hauw JJ, Javoy-Agid F, Agid Y (1993) Heterogeneity and selectivity of the degeneration of cholinergic neurons in the basal forebrain of patients with Alzheimer's disease. J Comp Neurol 330:15-31. CrossRef Medline

Li X, Yu B, Sun Q, Zhang Y, Ren M, Zhang X, Li A, Yuan J, Madisen L, Luo Q, Zeng H, Gong H, Qiu Z (2018) Generation of a whole-brain atlas for the cholinergic system and mesoscopic projectome analysis of basal forebrain cholinergic neurons. Proc Natl Acad Sci U S A 115:415-420. CrossRef Medline

Liu X, Ramirez S, Pang PT, Puryear CB, Govindarajan A, Deisseroth K, Tonegawa S (2012) Optogenetic stimulation of a hippocampal engram activates fear memory recall. Nature 484:381-385. CrossRef Medline

Lu H, Zou Q, Gu H, Raichle ME, Stein EA, Yang Y (2012) Rat brains also have a default mode network. Proc Natl Acad Sci U S A 109:3979-3984. CrossRef Medline

Madison DV, Lancaster B, Nicoll RA (1987) Voltage clamp analysis of cholinergic action in the hippocampus. J Neurosci 7:733-741. CrossRef Medline

Marrosu F, Portas C, Mascia MS, Casu MA, Fà M, Giagheddu M, Imperato A, Gessa GL (1995) Microdialysis measurement of cortical and hippocampal acetylcholine release during sleep-wake cycle in freely moving cats. Brain Res 671:329-332. CrossRef Medline

McCormick DA, McGinley MJ, Salkoff DB (2015) Brain state dependent activity in the cortex and thalamus. Curr Opin Neurobiol 31:133-140. CrossRef Medline

McGaughy J, Sarter M (1998) Sustained attention performance in rats with intracortical infusions of 192 IgG-saporin-induced cortical cholinergic deafferentation: effects of physostigmine and FG 7142. Behav Neurosci 112:1519-1525. CrossRef Medline

McGinley MJ, Vinck M, Reimer J, Batista-Brito R, Zagha E, Cadwell CR, Tolias AS, Cardin JA, McCormick DA (2015) Waking state: rapid variations modulate neural and behavioral responses. Neuron 87:1143-1161. CrossRef Medline

Metherate R, Hsieh CY (2003) Regulation of glutamate synapses by nicotinic acetylcholine receptors in auditory cortex. Neurobiol Learn Mem 80:285-290. CrossRef Medline

Minces V, Pinto L, Dan Y, Chiba AA (2017) Cholinergic shaping of neural correlations. Proc Natl Acad Sci U S A 114:5725-5730. CrossRef Medline

Momiyama T, Záborszky L (2006) Somatostatin presynaptically inhibits both GABA and glutamate release onto rat basal forebrain cholinergic neurons. J Neurophysiol 96:686-694. CrossRef Medline

Monmaur P, Collet A, Puma C, Frankel-Kohn L, Sharif A (1997) Relations between acetylcholine release and electrophysiological characteristics of theta rhythm: a microdialysis study in the urethane-anesthetized rat hippocampus. Brain Res Bull 42:141-146. CrossRef Medline

Monosov IE, Leopold DA, Hikosaka O (2015) Neurons in the primate basal forebrain signal combined information about reward uncertainty, value, and punishment anticipation. J Neurosci 35:7443-7459. CrossRef Medline

Muñoz W, Rudy B (2014) Spatiotemporal specificity in cholinergic control of neocortical function. Curr Opin Neurobiol 26:149-160. CrossRef Medline

Nair J, Klaassen AL, Arato J, Vyssotski AL, Harvey M, Rainer G (2018) Basal forebrain contributes to default mode network regulation. Proc Nat Sci U S A 115:1352-1357. CrossRef Medline

Nelson A, Mooney R (2016) The basal forebrain and motor cortex provide convergent yet distinct movement-related inputs to the auditory cortex. Neuron 90:635-648. CrossRef Medline

Newman EL, Climer JR, Hasselmo ME (2014) Grid cell spatial tuning reduced following systemic muscarinic receptor blockade. Hippocampus 24:643-655. CrossRef Medline

Nickerson Poulin A, Guerci A, El Mestikawy S, Semba K (2006) Vesicular glutamate transporter 3 immunoreactivity is present in cholinergic basal forebrain neurons projecting to the basolateral amygdala in rat. J Comp Neurol 498:690-711. CrossRef Medline

Niell CM, Stryker MP (2010) Modulation of visual responses by behavioral state in mouse visual cortex. Neuron 65:472-479. CrossRef Medline

Nonaka A, Toyoda T, Miura Y, Hitora-Imamura N, Naka M, Eguchi M, Yamaguchi S, Ikegaya Y, Matsuki N, Nomura H (2014) Synaptic plasticity associated with a memory engram in the basolateral amygdala. J Neurosci 34:9305-9309. CrossRef Medline

Obermayer J, Verhoog MB, Luchicchi A, Mansvelder HD (2017) Cholinergic modulation of cortical microcircuits is layer-specific: evidence from rodent, monkey and human brain. Front Neural Circuits 11:100. CrossRef Medline

Palop JJ, Mucke L (2010) Amyloid-beta-induced neuronal dysfunction in Alzheimer's disease: from synapses toward neural networks. Nat Neurosci 13:812-818. CrossRef Medline

Pang KC, Nocera R, Secor AJ, Yoder RM (2001) GABAergic septohippocampal neurons are not necessary for spatial memory. Hippocampus 11:814-827. CrossRef Medline

Parikh V, Kozak R, Martinez V, Sarter M (2007) Prefrontal acetylcholine release controls cue detection on multiple timescales. Neuron 56:141154. CrossRef Medline

Patil MM, Hasselmo ME (1999) Modulation of inhibitory synaptic potentials in the piriform cortex. J Neurophysiol 81:2103-2118. CrossRef Medline

Patil MM, Linster C, Lubenov E, Hasselmo ME (1998) Cholinergic agonist carbachol enables associative long-term potentiation in piriform cortex slices. J Neurophysiol 80:2467-2474. CrossRef Medline

Peterson RC (1977) Scopolamine-induced learning failures in man. Psychopharmacology (Berl) 52:283-289. CrossRef Medline

Picciotto MR, Higley MJ, Mineur YS (2012) Acetylcholine as a neuromodulator: cholinergic signaling shapes nervous system function and behavior. Neuron 76:116-129. CrossRef Medline

Pinto L, Goard MJ, Estandian D, Xu M, Kwan AC, Lee SH, Harrison TC, Feng G, Dan Y (2013) Fast modulation of visual perception by basal forebrain cholinergic neurons. Nat Neurosci 16:1857-1863. CrossRef Medline

Power AE, McGaugh JL (2002) Phthalic acid amygdalopetal lesion of the nucleus basalis magnocellularis induces reversible memory deficits in rats. Neurobiol Learn Mem 77:372-388. CrossRef Medline

Price JL, Stern R (1983) Individual cells in the nucleus basalis-diagonal band complex have restricted axonal projections to the cerebral cortex in the rat. Brain Res 20: 269:352-356. CrossRef Medline

Quinn LK, Nitz DA, Chiba AA (2010) Learning-dependent dynamics of beta-frequency oscillations in the basal forebrain of rats. Eur J Neurosci 32:1507-1515. CrossRef Medline

Ramaswamy S, Markram H (2018) Data-driven modeling of cholinergic modulation of neural microcircuits: bridging neurons, synapses and network states. bioRxiv. Retrieved May 16, 2018. Advance online publication. doi: 10.1101/323865. 
Redondo RL, Kim J, Arons AL, Ramirez S, Liu X, Tonegawa S (2014) Bidirectional switch of the valence associated with a hippocampal contextual memory engram. Nature 513:426-430. CrossRef Medline

Reijmers LG, Perkins BL, Matsuo N, Mayford M (2007) Localization of a stable neural correlate of associative memory. Science 317:1230-1233. CrossRef Medline

Reimer J, McGinley MJ, Liu Y, Rodenkirch C, Wang Q, McCormick DA, Tolias AS (2016) Pupil fluctuations track rapid changes in adrenergic and cholinergic activity in cortex. Nat Commun 7:13289. CrossRef Medline

Roberts MJ, Zinke W, Guo K, Robertson R, McDonald JS, Thiele A (2005) Acetylcholine dynamically controls spatial integration in marmoset primary visual cortex. J Neurophysiol 93:2062-2072. CrossRef Medline

Sahakian B, Jones G, Levy R, Gray J, Warburton D (1989) The effects of nicotine on attention, information processing, and short-term memory in patients with dementia of the alzheimer type. Br J Psychiatry 154:797800. CrossRef Medline

Saper CB (1984) Organization of cerebral cortical afferent systems in the rat. II. Magnocellular basal nucleus. J Comp Neurol 222:313-342. CrossRef Medline

Saper CB (1987) Diffuse cortical projection systems: anatomical organization and role in cortical function. In: Handbook of physiology: The nervous system, Vol 5, Pt 1 (Mountcastle VB, Plum F, Geiger S, eds), pp 169-210. Bethesda, Maryland: American Physiological Society.

Sarter M, Kim Y (2015) Interpreting chemical neurotransmission in vivo: techniques, time scales, and theories. ACS Chem Neurosci 6:8-10. CrossRef Medline

Sarter M, Hasselmo ME, Bruno JP, Givens B (2005) Unraveling the attentional functions of cortical cholinergic inputs: interactions between signal-driven and cognitive modulation of signal detection. Brain Res Rev 48:98-111. CrossRef Medline

Schmitz TW, Duncan J (2018) Normalization and the cholinergic microcircuit: a unified basis for attention. Trends Cogn Sci 22:422-437. CrossRef Medline

Schwindt PC, Spain WJ, Foehring RC, Chubb MC, Crill WE (1988) Slow conductances in neurons from cat sensorimotor cortex in vitro and their role in slow excitability changes. J Neurophysiol 59:450-467. CrossRef Medline

Sehgal M, Ehlers VL, Moyer JR Jr (2014) Learning enhances intrinsic excitability in a subset of lateral amygdala neurons. Learn Mem 21:161-170. CrossRef Medline

Seol GH, Ziburkus J, Huang S, Song L, Kim IT, Takamiya K, Huganir RL, Lee HK, Kirkwood A (2007) Neuromodulators control the polarity of spiketiming-dependent synaptic plasticity. Neuron 55:919-929. CrossRef Medline

Silver MA, Shenhav A, D’Esposito M (2008) Cholinergic enhancement reduces spatial spread of visual responses in human early visual cortex. Neuron 60:904-914. CrossRef Medline

Sorg C, Riedl V, Mühlau M, Calhoun VD, Eichele T, Läer L, Drzezga A, Förstl H, Kurz A, Zimmer C, Wohlschläger AM (2007) Selective changes of resting-state networks in individuals at risk for Alzheimer's disease. Proc Natl Acad Sci U S A 104:18760-18765. CrossRef Medline

Staples LG (2010) Predator odor avoidance as a rodent model of anxiety: learning-mediated consequences beyond the initial exposure. Neurobiol Learn Mem 94:435-445. CrossRef Medline

Teles-Grilo Ruivo LM, Baker KL, Conway MW, Kinsley PJ, Gilmour G, Phillips KG, Isaac JTR, Lowry JP, Mellor JR (2017) Coordinated acetylcholine release in prefrontal cortex and hippocampus is associated with arousal and reward on distinct timescales. Cell Rep 18:905-917. CrossRef Medline

Tingley D, Alexander AS, Kolbu S, de Sa VR, Chiba AA, Nitz DA (2014) Task-phase-specific dynamics of basal forebrain neuronal ensembles. Front Syst Neurosci 8:174. CrossRef Medline

Tingley D, Alexander AS, Quinn LK, Chiba AA, Nitz DA (2015) Cell assemblies of the basal forebrain. J Neurosci 35:2992-3000. CrossRef Medline

Tingley D, Alexander AS, Quinn LK, Chiba AA, Nitz D (2018) Multiplexed oscillations and phase-rate coding in the basal forebrain. Sci Adv 4:eaar3230. CrossRef Medline

Tóth A, Záborszky L, Détári L (2005) EEG effect of basal forebrain neuropeptide $\mathrm{Y}$ administration in urethane anaesthetized rats. Brain Res Bull 66:37-42. CrossRef Medline

Tóth A, Hajnik T, Záborszky L, Détári L (2007) Effect of basal forebrain neuropeptide $\mathrm{Y}$ administration on sleep and spontaneous behavior in freely moving rats. Brain Res Bull 72:293-301. CrossRef Medline

Unal CT, Golowasch JP, Záborszky L (2012) Adult mouse basal forebrain harbors two distinct cholinergic populations defined by their electrophysiology. Front Behav Neurosci 6:21. CrossRef Medline

Unal CT, Pare D, Záborszky L (2015) Impact of basal forebrain cholinergic inputs on basolateral amygdala neurons. J Neurosci 35:853-863. CrossRef Medline

Valentino RJ, Dingledine R (1981) Presynaptic inhibitory effect of acetylcholine in the hippocampus. J Neurosci 1:784-792. CrossRef Medline

Vandecasteele M, Varga V, Berényi A, Papp E, Barthó P, Venance L, Freund TF, Buzsáki G (2014) Optogenetic activation of septal cholinergic neurons suppresses sharp wave ripples and enhances theta oscillations in the hippocampus. Proc Natl Acad Sci U S A 111:13535-13540. CrossRef Medline

Verhoog MB, Obermayer J, Kortleven CA, Wilbers R, Wester J, Baayen JC, De Kock CP, Meredith RM, Mansvelder HD (2016) Layer-specific cholinergic control of human and mouse cortical synaptic plasticity. Nat Commun 7:12826. CrossRef Medline

Vidal C, Changeux JP (1993) Nicotinic and muscarinic modulations of excitatory synaptic transmission in the rat prefrontal cortex in vitro. Neuroscience 56:23-32. CrossRef Medline

Vogt KE, Regehr WG (2001) Cholinergic modulation of excitatory synaptic transmission in the CA3 area of the hippocampus. J Neurosci 21:75-83. CrossRef Medline

Vyazovskiy VV, Olcese U, Hanlon EC, Nir Y, Cirelli C, Tononi G (2011) Local sleep in awake rats. Nature 472:443-447. CrossRef Medline

Wesnes K, Warburton DM (1984) Effects of scopolamine and nicotine on human rapid information processing performance. Psychopharmacology (Berl) 82:147-150. CrossRef Medline

Williams S, Johnston D (1990) Muscarinic depression of synaptic transmission at the hippocampal mossy fiber synapse. J Neurophysiol 64:10891097. CrossRef Medline

Wilson MA, McNaughton BL (1994) Reactivation of hippocampal ensemble memories during sleep. Science 265:676-679. CrossRef Medline

Winson J, Abzug C (1977) Gating of neuronal transmission in the hippocampus: efficacy of transmission varies with behavioral state. Science 196:1223-1225. CrossRef Medline

Xu M, Chung S, Zhang S, Zhong P, Ma C, Chang WC, Weissbourd B, Sakai N, Luo L, Nishino S, Dan Y (2015) Basal forebrain circuit for sleep-wake control. Nat Neurosci 18:1641-1647. CrossRef Medline

Yang C, McKenna JT, Zant JC, Winston S, Basheer R, Brown RE (2014) Cholinergic neurons excite cortically projecting basal forebrain GABAergic neurons. J Neurosci 34:2832-2844. CrossRef Medline

Yiu AP, Mercaldo V, Yan C, Richards B, Rashid AJ, Hsiang HL, Pressey J, Mahadevan V, Tran MM, Kushner A, Woodin MA, Frankland PW, Josselyn SA (2014) Neurons are recruited to a memory trace based on relative neuronal excitability immediately before training. Neuron 83 : 722-735. CrossRef Medline

Yoder RM, Chan JHM, Taube JS (2017) Acetylcholine contributes to the integration of self-movement cues in head direction cells. Behav Neurosci 131:312-324. CrossRef Medline

Young KA, Brown MC, Kelley CF, Hasselmo ME (2017) Cholinergic modulation of interneurons in the medial entorhinal cortex. Soc Neurosci Abstr 43:83.26.

Yuan R, Biswal BB, Záborszky L (2018) Functional subdivisions of magnocellular cell groups in human basal forebrain: test-retest resting-state study at ultra-high field, and meta-analysis. Cereb Cortex Retrieved Aug 23, 2018. Advance online publication. doi: 10.1093/cercor/bhy150.

Záborszky L (1989) Afferent connections of the forebrain cholinergic projection neurons, with special reference to monoaminergic and peptidergic fibers. In: Central cholinergic synaptic transmission (Frotscher M, Misgeld U, eds), pp 12-32. Basel: Birkhauser.

Záborszky L, Duque A (2000) Local synaptic connections of basal forebrain neurons. Behav Brain Res 115:143-158. CrossRef Medline

Záborszky L, Gombkoto P (2018) The cholinergic multicompartmental basal forebrain microcircuit. In: Handbook of brain microcircuits (Shepherd GM, Grillner S, eds), pp 163-183. New York: OUP.

Záborszky L, Heimer L, Eckenstein F, Leranth C (1986) GABAergic input to cholinergic forebrain neurons: an ultrastructural study using retrograde tracing of HRP and double immunolabeling. J Comp Neurol 250:282295. CrossRef Medline 
Záborszky L, Csordas A, Buhl DL, Duque A, Somogyi J, Nadasdy Z (2002) Computational anatomical analysis of the basal forebrain corticopetal system. In: Computational neuroanatomy: principles and methods (Ascoli GA, ed), pp 171-197. Totowa, NJ: Humana.

Záborszky L, Hoemke L, Mohlberg H, Schleicher A, Amunts K, Zilles K (2008) Stereotaxic probabilistic maps of the magnocellular cell groups in human basal forebrain. Neuroimage 42:1127-1141. CrossRef Medline

Záborszky L, Duque A, Alreja M, Saak SV (2009) Effect of NPY in the cholinergic basal forebrain in rat: a double-immunolabeling electron microscopy and in vitro electrophysiological studies. Soc Neurosci Abstr 35:P2.1.04.

Záborszky L, Csordas A, Mosca K, Kim J, Gielow MR, Vadasz C, Nadasdy Z (2015a) Neurons in the basal forebrain project to the cortex in a complex topographic organization that reflects corticocortical connectivity patterns: an experimental study based on retrograde tracing and 3D reconstruction. Cereb Cortex 25:118-137. CrossRef Medline

Záborszky L, Duque A, Gielow M, Gombkoto P, Nadasdy Z, Somogyi J (2015b) Organization of the basal forebrain cholinergic projection system: Specific or diffuse? In: The rat nervous system, 4th ed (Paxinos G, ed), pp 491-507. Amsterdam: Elsevier.

Záborszky L, Amunts K, Palomero-Gallagher N, Zilles K (2015c) Basal forebrain anatomical systems in MRI space. In: Brain mapping: an encyclopedic reference. (Toga A, ed), pp 395-409. Amsterdam: Elsevier.

Zant JC, Kim T, Prokai L, Szarka S, McNally J, McKenna JT, Shukla C, Yang C, Kalinchuk AV, McCarley RW, Brown RE, Basheer R (2016) Cholinergic neurons in thebasal forebrain promote wakefulness by actions on neighboring non-cholinergicneurons: an opto-dialysis study. J Neurosci 36:2057-2067. CrossRef Medline

Zhang H, Lin SC, Nicolelis MA (2010) Spatiotemporal coupling between hippocampal acetylcholine release and theta oscillations in vivo. J Neurosci 30:13431-13440. CrossRef Medline

Zhang Y, Cao SX, Sun P, He HY, Yang CH, Chen XJ, Shen CJ, Wang XD, Chen Z, Berg DK, Duan S, Li XM (2016) Loss of MeCP2 in cholinergic neurons causes part of RTT-like phenotypes via $\alpha 7$ receptor in hippocampus. Cell Res 26:728-742. CrossRef Medline 